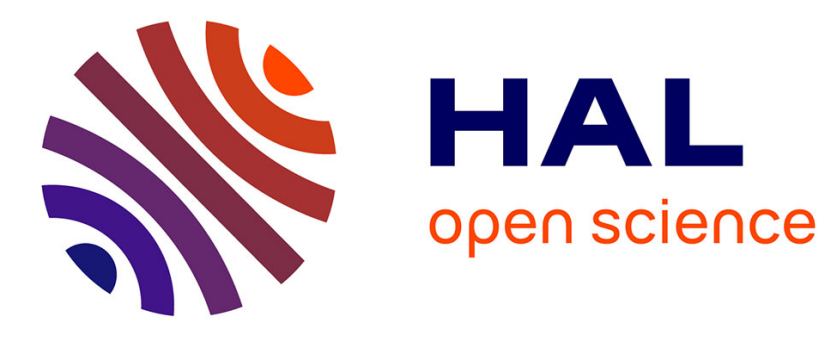

\title{
Dynamic biomechanical modelling for foot ulcer prevention.
}

\author{
Vincent Luboz, Antoine Perrier, Marek Bucki, Francis Cannard, Bruno Diot, \\ Nicolas Vuillerme, Yohan Payan
}

\section{- To cite this version:}

Vincent Luboz, Antoine Perrier, Marek Bucki, Francis Cannard, Bruno Diot, et al.. Dynamic biomechanical modelling for foot ulcer prevention.. Computer Methods in Biomechanics and Biomedical Engineering, 2013, 16 Suppl 1, pp.149-51. 10.1080/10255842.2013.815863 . hal-00854125

\section{HAL Id: hal-00854125 \\ https://hal.science/hal-00854125}

Submitted on 26 Aug 2013

HAL is a multi-disciplinary open access archive for the deposit and dissemination of scientific research documents, whether they are published or not. The documents may come from teaching and research institutions in France or abroad, or from public or private research centers.
L'archive ouverte pluridisciplinaire HAL, est destinée au dépôt et à la diffusion de documents scientifiques de niveau recherche, publiés ou non, émanant des établissements d'enseignement et de recherche français ou étrangers, des laboratoires publics ou privés. 


\title{
Dynamic biomechanical modeling for foot ulcer prevention
}

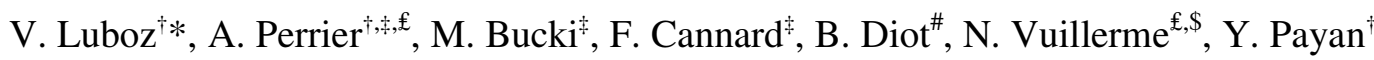 \\ ${ }^{\dagger}$ Laboratoire TIMC, France; ${ }^{\ddagger}$ TexiSense, France; ${ }^{\ddagger}$ Laboratoire AGIM, France; ${ }^{\#} I D S ;{ }^{\$} I U F$, France
}

Keywords: foot ulcer prevention; biomechanical model; dynamic analysis

\section{Introduction}

Most foot ulcers are the consequence of a trauma (repetitive high stress, ill-fitting footwear, or an object inside the shoe) associated to diabetes. They are often followed by amputation and shorten life expectancy [Reiber, 2010]. Because of somatosensory deficits, diabetic patients cannot perceive the pain announcing deep tissue injury and their natural defense is thus altered. Today, prevention is mainly based on the patient's daily vigilance and on doctor monitoring. Although several devices aim at reducing pressure loading to facilitate wound healing [Armstrong, 1998], little has been done to prevent ulcer creations, especially because they stem from high stresses and strains inside the tissues at the boundary with bony prominences. Such ulcers usually start in deep tissues and progress outward rapidly, causing substantial subcutaneous damage underneath intact skin. Deep pressure ulcers are therefore particularly dangerous since they may be difficult to detect visually. Devices measuring surface pressures are mainly used to alert persons suffering from diabetes to abnormal pressures that may cause skin damage [Pipkin, 2008]. These measurements, however, cannot predict ulcer from internal tissue loading [Linder-Ganz, 2008]. We plan to assess ulceration risks by estimating the internal strains within the patient's foot through a biomechanical model of the foot driven by plantar pressures measured with a commercial sensor while a subject walks.

\section{Methods}

The foot model runs on Artisynth (artisynth.org), a 3D biomechanical simulation platform. It integrates soft tissues, bones, joints and ligaments.

The soft tissues are divided into skin, muscles and fat. They are modelled as a finite element (FE) mesh. Its outer surface is inspired by the skin surface from the Zygote database (zygote.com). An automatic hexahedron-dominant FE mesh generator [Lobos, 2010] was used to mesh the soft tissues, Fig. 1, with 36,894 elements and 22,774 nodes.

The skin layer, which is one element thick, is split into two Neo Hookean materials: the plantar skin with $\mathrm{E}=6 \mathrm{GPa}$ [Sofer, 2011] and the rest of the skin with $\mathrm{E}=200 \mathrm{kPa}$. They both have a Poisson ratio of 0.495 . The elasticity modulus chosen for the rest of the skin was measured on the foot arch of a young healthy subject using our own device: LASTIC (for Light Aspiration device for in vivo Soft TIssue Characterization). This device is based on the pipette aspiration principle and aims at characterizing in vivo the elastic modulus of soft tissues. As can be seen on Fig. 1, the plantar skin is composed of the elements below the heel, the metatarsi and the toes.

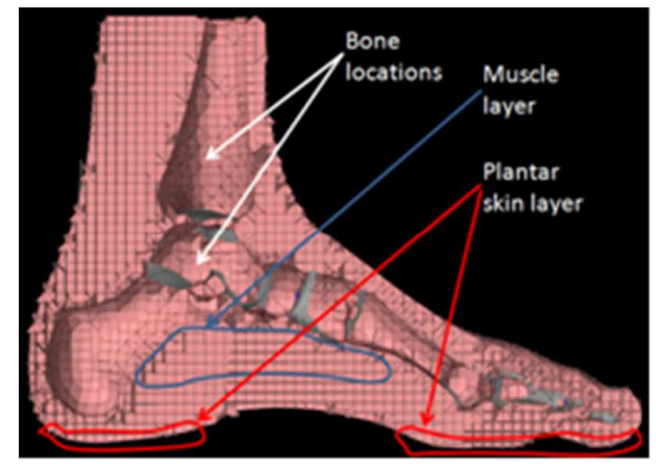

Figure 1 Cross section of the FE mesh with its different layers: skin, muscles and bones. Only the surface elements into the red areas define the plantar skin, the rest forms the softer skin layer. The other internal elements form the fat layer.

Muscles and fat are also modelled as two Neo Hookean materials with Young moduli of $50 \mathrm{kPa}$ and $4 \mathrm{kPa}$, respectively and Poisson ratios of 0.495 [Sofer, 2011]. The muscle layer is defined from the Zygote database and is limited for now to the muscles of the foot arch. This area was mapped in the FE mesh to find the elements considered as muscles. The elements that are neither in the skin layer nor in the muscle layer are assumed to be part of the fat layer.

The 26 foot bones and a section of the tibia and fibula are modelled as rigid body surfaces. Their morphology was defined by the Zygote database. Each rigid body is fixed to the nearby finite element nodes of the soft tissue mesh to naturally rigidify the foot. The 33 foot joints are simulated by pivots connecting each bone with its neighbours. Their angles of rotation vary from 45 degrees for the phalanx pivots to 5 degrees for the others. Four large ligaments constrain the model: the internal

\footnotetext{
*Corresponding author. Email: vincent.luboz@imag.fr
} 
and external plantar fasciae, the Achilles tendon, and the transversal metatarsal head ligament. They are simulated as cables with an extension stiffness of $200 \mathrm{MPa}$ and a compression stiffness of $0 \mathrm{MPa}$ as extrapolated from [Gefen, 2003]. Their insertion sites were defined by an experienced podiatrist.

\section{Results and Discussion}

As pressure ulcers seem mainly induced by internal strains [Loerakker, 2011], our model is used to monitor their range in a dynamic setting at two key positions: (a) when both feet are fully on the ground, and (b) when the weight is only on the front of one foot (toes and metatarsi), starting walking. Plantar pressures are thus measured with a Zebris platform (zebris.de) for these two positions on a young healthy subject, Fig. 2. In terms of boundary conditions, the tibia and fibula are fixed while the measured pressures are applied to the foot model sole. Their values range from 0 to $10 \mathrm{~N} . \mathrm{cm}^{-2}$ for (a) and from 0 to $25 \mathrm{~N} . \mathrm{cm}^{-2}$ during (b).

Table 1 shows Von Mises strains computed by the model below the metatarsal heads and the heel externally (at the skin surface) and internally (near the bony prominences), where the maximal strains are observed, for the two foot positions. Internal strains are higher than external strains, realistically replicating a possible foot ulceration scenario. Furthermore, the strain difference between (a) and (b) shows that our model can handle the changes linked to a dynamic analysis of the foot position.

\begin{tabular}{|l|r|r|r|r|}
\hline Location & $\begin{array}{c}\text { (a) Ext. } \\
\text { strain }\end{array}$ & $\begin{array}{c}\text { (a) Int. } \\
\text { strain }\end{array}$ & $\begin{array}{c}\text { (b)Ext. } \\
\text { strain }\end{array}$ & $\begin{array}{c}\text { (b) Int. } \\
\text { strain }\end{array}$ \\
\hline $5^{\text {th }}$ MTT & $1.8 \%$ & $72.7 \%$ & $3.7 \%$ & $171 \%$ \\
\hline $4^{\text {th }}$ MTT & $2.8 \%$ & $83.4 \%$ & $6.3 \%$ & $204 \%$ \\
\hline $3^{\text {rd }}$ MTT & $4.5 \%$ & $81.8 \%$ & $6.5 \%$ & $152 \%$ \\
\hline $2^{\text {nd }}$ MTT & $3.2 \%$ & $33.4 \%$ & $5.1 \%$ & $31.6 \%$ \\
\hline $1^{\text {st }}$ MTT & $3.3 \%$ & $37.5 \%$ & $7.7 \%$ & $92.6 \%$ \\
\hline Heel & $1.8 \%$ & $137 \%$ & $0.6 \%$ & $59.3 \%$ \\
\hline
\end{tabular}

Table 1 Von Mises strains measured under the metatarsal head (MTT) of each toe and under the heel, internally (just below the bone structure) and externally (at the skin surface) for (a) two feet fully on the ground, and (b) weight only on a foot front

\section{Conclusions}

Our biomechanical model allows computing the strains under and within the foot for different foot positions. It shows a realistic behaviour in these positions in terms of surface and internal strains with plantar pressures measured with a commercial sensor. Average surface strains of $2.9 \%$ and $5 \%$ were evaluated on the skin surface below the heel and metatarsal heads while strains of $74.3 \%$ and $118.4 \%$ were measured internally, next to the bones, while (a) the subject foot was fully on the ground and (b) only the foot front, respectively. The analysis of internal strains caused by prescribed external loads enables localization of higher deformations inside the foot. Consequently, the model could therefore define an objective risk assessment scale for foot ulcer prevention while walking or standing, when coupled to the output of a plantar pressure sensor.

Future works will aim at linking this model with real-time data flow provided by pressure sensors to enable continuous monitoring of the internal strains within the diabetic patient's foot necessary for daily foot ulcer prevention. The main challenge, i.e. decreasing the model's computation time, will be addressed either by reducing the number of elements in zones less involved in ulcer formation or by limiting the FE modelling to ulcer prone areas such as the heel and the metatarsal heads.

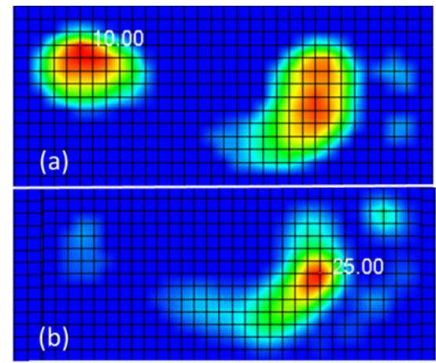

Figure 2 Pressures measured with the Zebris platform when (a) two feet are fully on the ground, and (b) the weight is only on the front of one foot.

\section{Acknowledgments}

This work is partly funded by the 2010 ANR TecSan IDS project and by the CAMI Labex.

\section{References}

Armstrong DG., Lavery LA. 1998. Evidence-based options for off-loading diabetic wounds. Clin Podiatr Med Surg; Vol. 15, pp. 95-104.

Gefen A. 2003. Plantar soft tissue loading under the medial metatarsals in the standing diabetic foot. Med. Eng. \& Physics, Vol. 25, pp. 491-499.

Linder-Ganz E. et al. 2008. Strains and stresses in sub-dermal tissues of the buttocks are greater in paraplegics than in healthy during sitting. Journal of Biomechanics. Vol 41, pp. 567-580.

Lobos C. et al. 2010. Techniques for the generation of 3D Finite Element Meshes of human organs. Informatics Oral Med.: Advanced Techniques in Clinical and Diagnostic Tech. pp. 126-158.

Loerakker, S. et al. 2011. Effects of deformation, ischemia, and reperfusion on the development of muscle damage during prolonged loading. J. Applied Physiology, 111(4), 1168-1177.

Pipkin L., Sprigle S. 2008. Effect of model design, cushion construction, and interface pressure mats on interface pressure and immersion. $\mathrm{J}$ Rehabil Res Dev, Vol. 45, pp. 875-882.

Reiber GE. 2010. Epidemiology of Foot Ulceration and Amputations in Diabetes, 6th ed., Mosby.

Sopher R. et al. 2011. The influence of foot posture and tissue properties on biomechanical factors associated with a risk of heel ulceration. $\mathrm{J}$ Mech Behav Biomed Mater, Vol. 4(4), pp. 572-82. 